\title{
Qualities
}

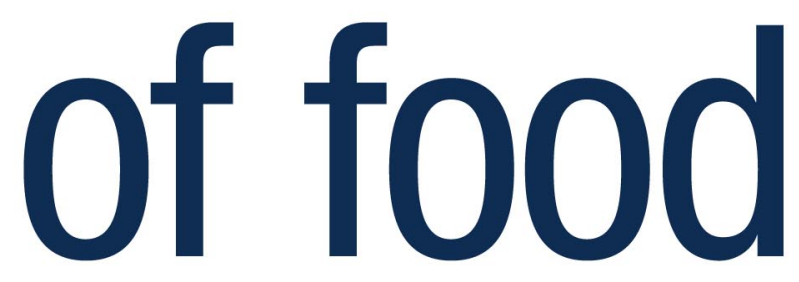

edited by Mark Harvey, Andrew McMeekin and Alan Warde
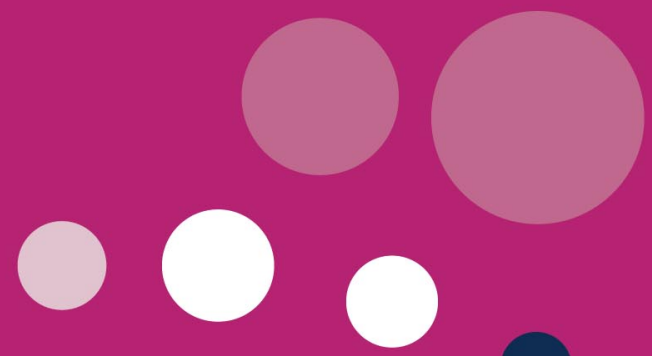

8
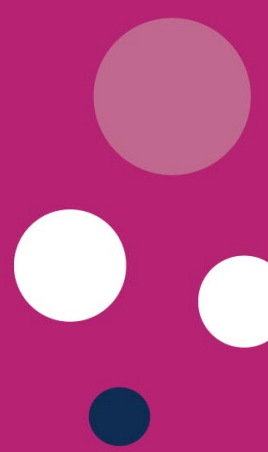

$\longrightarrow$
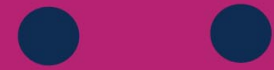


\section{Qualities of food}

Published in our

centenary year

$\approx 2004 \curvearrowleft$

MANCHESTER

UNIVERSITY

PRESS 


\section{New Dynamics of Innovation and Competition}

The series New Dynamics of Innovation and Competition, published in association with the ESRC Centre for Research in Innovation and Competition at the University of Manchester and UMIST emanates from an engagement of the Centre's research agenda with a wide range of internationally renowned scholars in the field. The series casts new light on the significance of demand and consumption, markets and competition, and the complex inter-organisational basis for innovation processes. The volumes are multidisciplinary and comparative in perspective.

Series editor:

Mark Harvey, Senior Research Fellow at CRIC

Already published:

Innovation by demand: an interdisciplinary approach to the study of demand and its role in innovation Andrew McMeekin, Ken Green, Mark Tomlinson and Vivien Walsh (eds)

Market relations and the competitive process: new dynamics of innovation and competition Stan Metcalfe and Alan Warde (eds) 


\section{Qualities of food}

edited by

Mark Harvey

Andrew McMeekin

Alan Warde

Manchester University Press

Manchester and New York

distributed exclusively in the USA by Palgrave 
Copyright (C) Manchester University Press 2004

While copyright in the volume as a whole is vested in Manchester University Press, copyright in individual chapters belongs to their respective authors, and no chapter may be reproduced wholly or in part without the express permission in writing of both author and publisher.

Published by Manchester University Press

Oxford Road, Manchester M13 9NR, UK

and Room 400, 175 Fifth Avenue, New York, NY 10010, USA

www.manchesteruniversitypress.co.uk

Distributed exclusively in the USA by

Palgrave, 175 Fifth Avenue, New York,

NY 10010, USA

Distributed exclusively in Canada by

UBC Press, University of British Columbia, 2029 West Mall,

Vancouver, BC, Canada V6T 1 Z2

British Library Cataloguing-in-Publication Data

A catalogue record for this book is available from the British Library

Library of Congress Cataloging-in-Publication Data applied for

ISBN 0719068541 hardback

EAN $\quad 9780719068546$

First published 2004

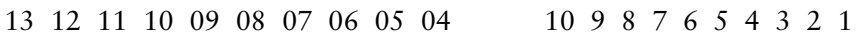

Typeset in Sabon with Helvetica Neue Condensed (HNC)

by Northern Phototypesetting Co. Ltd, Bolton

Printed in Great Britain

by Biddles Ltd, King's Lynn 